\title{
Nonredundant Roles for Basophils in Immediate- and Delayed-onset Allergic Reactions
}

\author{
Hajime Karasuyama ${ }^{1,2}$, Kaori Mukai ${ }^{1}$, Kazushige Obata ${ }^{1}$, Yusuke Tsujimura ${ }^{1}$, Yohei Kawano ${ }^{1}$, \\ and Yoshiyuki Minegishi, ${ }^{1,2}$
}

\author{
${ }^{1}$ Department of Immune Regulation, ${ }^{2}$ JST, CREST, Tokyo Medical and Dental University Graduate School, Tokyo 113- \\ 8519, Japan
}

\begin{abstract}
Basophils circulate in the peripheral blood under physiological conditions, and they are recruited to affected tissues in allergic reactions, albeit in small numbers. Because of their rarity (less than $1 \%$ of peripheral blood leukocytes are basophils), and their similarity to mast cells, basophils have often been considered the lesser relatives of mast cells. Moreover, because basophils have been so difficult to identify, mice were erroneously believed for a long time to lack them. Therefore, the assumption that basophils have only redundant roles has remained unquestioned until recently. The flow-cytometric identification of basophils in mice and the development of in vivo models and reagents useful for their functional analyses have greatly advanced the field of basophil research. Previously unrecognized roles of basophils, distinct from those of mast cells, have been shown in allergic responses and the regulation of acquired immunity. In this review, we mainly focus on roles of basophils in immediate- and delayed-onset allergic reactions. Basophils are crucial initiators, rather than effectors, in the development of IgE-mediated, chronic cutaneous allergic inflammation, which is characterized by the massive infiltration of eosinophils and neutrophils and can be elicited even in the absence of mast cells and $\mathrm{T}$ cells. Basophils are dispensable for the induction of IgE-mediated systemic anaphylaxis, unlike mast cells, but play a major role in IgG-mediated passive and active systemic anaphylaxis, through the release of platelet-activating factor in response to stimulation with antigen-IgG immune complexes. Thus, basophils and their products appear to be promising therapeutic targets for allergic disorders.
\end{abstract}

Key Words: Basophils, anaphylaxis, allergic inflammation.

\section{INTRODUCTION}

Basophils are the least common granulocytes, accounting for less than $1 \%$ of peripheral blood leukocytes. Even though their lineage, with regard to other hematopoietic cells, and how they differentiate from hematopoietic stem cells in the bone marrow remain uncertain, basophils share several features with mast cells, including the presence of basophilic granules in the cytoplasm, the surface expression of the highaffinity receptor FceRI, and the release of allergy-inducing chemical mediators such as histamine and leukotrienes [1-3]. Furthermore, because the identification of mouse basophils by conventional methods, such as Giemsa staining, is extremely difficult $[4,5]$, for a long time people erroneously concluded that mice lack basophils [6]. Therefore, basophils have been the 'ugly stepchild' of leukocytes, and most of the attention has focused on mast cells. The discovery in the early 1990s that basophils are an important source of Th2 cytokines, including IL-4 [7-10], greatly changed the view that they are a minor and redundant, circulating variant of tissue-resident mast cells, and suggested that basophils might contribute to allergic responses and to protective immunity against parasites [11-13].

*Address correspondence to this author at the Department of Immune Regulation, Tokyo Medical and Dental University Graduate School, 1-5-45 Yushima, Bunkyo-ku, Tokyo 113-8519, Japan; Tel: +81-3-5803-5162; Fax: +81-3-3814-7172; E-mail: karasuyama.mbch@tmd.ac.jp
Basophils are often recruited to the site of allergic inflammation, albeit in small numbers [14-19]. However, the direct assessment of their roles in allergic responses was hampered by the absence of suitable models, including mice deficient only in basophils. Recent studies have overcome this obstacle by creating new tools such as basophildepleting antibodies [20-23], and previously unrecognized roles for basophils have been demonstrated in vivo [24-33]. In this review, we highlight the nonredundant roles played by basophils in immediate- and delayed-onset allergic reactions.

\section{THE ROLE OF BASOPHILS IN DELAYED-ONSET AND CHRONIC ALLERGIC INFLAMMATION}

\section{Basophils in Jones-Mote hypersensitivity and cutaneous basophil hypersensitivity}

During the first golden age of basophil research, the 1970s, extensive studies were performed on the cutaneous delayed-type hypersensitivity reaction that is characterized by a massive dermal infiltration of basophils [34]. This reaction is distinct from the classical, delayed-type hypersensitivity (DTH) reaction, and therefore was originally termed "Jones-Mote hypersensitivity" (JMH) in humans [35]. Later, the reaction was called "cutaneous basophil hypersensitivity" $(\mathrm{CBH})[36,37]$, mainly in guinea pig studies. While the immunization of animals with protein antigens in complete Freund's adjuvant containing mycobacterial components is usually required to elicit DTH, CBH can be elicited by im- 
munizing animals, particularly guinea pigs, with proteins alone or in incomplete Freund's adjuvant without mycobacterial components, and is induced only soon after the immunization [36]. In DTH, an intradermal challenge with antigens induces a skin reaction characterized by erythema and induration, which reaches its maximal intensity within 24 to $30 \mathrm{hr}$. The skin remains indurated for 48 to $72 \mathrm{hr}$. In contrast, $\mathrm{CBH}$ is characterized by erythema and slight thickening without apparent induration, peaks $18 \sim 24 \mathrm{hr}$ after the antigen challenge, and fades by $48 \mathrm{hr}$. In typical CBH lesions, basophils comprise 50 90\% of the papillary dermal infiltrates [37]. This is in sharp contrast to the DTH lesions, in which basophil recruitment is rarely detected.

$\mathrm{CBH}$ reactions exhibit heterogeneous pathogenicity. It was originally reported that the adoptive transfer of lymphocytes, most likely $\mathrm{T}$ cells, but not serum from sensitized guinea pigs causes $\mathrm{CBH}$ in naïve animals [38], in a manner analogous to DTH, but distinct from the antibody-mediated, immediate hypersensitivity reaction. However, later studies showed that $\mathrm{CBH}$ can be induced by the passive transfer of IgG1 or IgE from sensitized guinea pigs to naïve ones [39, 40]. Thus, the mechanism by which the $\mathrm{CBH}$ response, including basophil recruitment, is triggered remains uncertain, as does the role of basophils in $\mathrm{CBH}$. The treatment of guinea pigs with anti-basophil serum before the antigen challenge results in increased rather than decreased erythema, concomitant with a reduced number of basophils in the skin lesions [41], suggesting that basophils may play an antiinflammatory role in $\mathrm{CBH}$.

The golden age of basophil research on JMH and $\mathrm{CBH}$ was over by the early 1980 s, as judged from the number of publications on these reactions. This may have come, in part, from the above-mentioned unexpected result, which disappointingly argued against a role for basophils as initiators or effectors in $\mathrm{CBH}$. Moreover, detailed analyses of the cellular and molecular mechanisms underlying $\mathrm{CBH}$ were hampered by the absence of mouse models of $\mathrm{CBH}$. The typical $\mathrm{CBH}$ reaction, i.e., characterized by a massive infiltration of basophils, was reportedly not elicited in mice. This might have been due to the difficulty in identifying mouse basophils in tissue sections [4-6], compared to guinea pig basophils. Therefore, the nature of $\mathrm{CBH}$ in mice and the role of basophils in it require reevaluation.

\section{Basophils in antigen-specific, IgE-mediated chronic al- lergic inflammation in mice}

In sensitized individuals, allergen challenge typically induces two sequential allergic responses. The immediatephase reaction develops within minutes of allergen exposure, while the late-phase reaction occurs within hours. When antibodies of the IgE class are produced against a given allergen in sensitized individuals, they circulate in the peripheral blood and bind to FceRI on circulating basophils and tissueresident mast cells. Re-exposure to the same allergen triggers the activation of mast cells and basophils through the crosslinking of IgE-bound FceRI by the allergen [42]. The major features of the immediate-phase reaction and at least some features of the late-phase reaction are explained by the actions of chemical mediators, cytokines and chemokines, that are released from activated mast cells, and perhaps from basophils [43-45]. By contrast, the roles of IgE, mast cells, and basophils are less clear in the pathogenesis of chronic allergic inflammation, which can persist for days to years, as observed in chronic allergic disorders, including atopic dermatitis and asthma.

To understand the in vivo roles of $\mathrm{IgE}$ under physiological and pathological conditions, and the cellular and molecular basis of IgE-mediated allergic reactions, we have created IgE transgenic mice that constitutively produce monoclonal IgE specific to hapten 2,4,6-trinitrophenol (TNP) [46]. Giving these mice an intravenous injection of the corresponding antigen, TNP-conjugated ovalbumin (TNP-OVA), induces antigen-specific systemic anaphylaxis and a drop in body temperature [46], indicating that the transgenic IgE functions in vivo. To examine local allergic reactions, we challenged the IgE transgenic mice with an intradermal injection of TNP-OVA or control OVA. Unexpectedly, the TNP-OVA administration induced three waves of ear swelling [24, 47]. The first two were typical immediate-type skin reactions: the early-phase ear swelling occurred within $1 \mathrm{hr}$ of the antigen challenge, followed by a late-phase, milder ear swelling 6-10 hr later. Notably, after the late-phase ear swelling subsided, ear swelling started again on day 1 2 and peaked on day 3 4 post-challenge. This delayed-onset, third ear swelling was more intense than the first and second ones. The ear skin was congested, and the ear swelled to twice its basal thickness or the thickness of ears challenged with control OVA. The time course of ear swelling in the third reaction resembled that observed in the classical DTH reaction mediated by $\mathrm{T}$ cells. However, histopathological analysis revealed that the skin lesions in the third reaction were distinct from those observed in DTH, showing a massive infiltration of cells, predominantly eosinophils and neutrophils [24, 47]. Therefore, we designated this antigen-specific, delayed-onset cutaneous reaction, "IgE-mediated chronic allergic inflammation" (IgECAI) [24]. We found that a comparable triphasic ear swelling could be elicited even in non-transgenic mice that had been passively sensitized with intravenous injection of antiTNP IgE one day before the challenge with TNP-OVA [24]. This finding demonstrated that the development of IgE-CAI was not an artifact derived from the transgenic expression of IgE, and made it possible to investigate IgE-CAI in various mutant mice without crossing them to the $\mathrm{IgE}$ transgenic mice.

Anti-histamine treatment efficiently suppressed both the immediate- and late-phase ear swelling, but showed no significant effect on the IgE-CAI, which instead responded to immunosuppressants like cyclosporine A or corticosteroids [47], suggesting that $\mathrm{T}$ cells might be involved in IgE-CAI development. However, IgE-CAI, including the eosinophilic infiltration of the skin lesions, was elicited normally in $\mathrm{T}$ cell-deficient mice [24], which showed that $\mathrm{T}$ cells are dispensable for the development of IgE-CAI. Mast celldeficient mice also exhibited the IgE-CAI response, although they failed to show the early- and late-phase ear swelling, which indicated that mast cells are not essential for IgE-CAI, and that the immediate- and late-phase reactions mediated by mast cells are not prerequisite for the development of IgECAI [24].

Two types of IgE receptors are known, the high-affinity receptor FceRI and the low-affinity receptor CD23 (also 


\section{IgE-mediated chronic allergic inflammation}

\section{IgG-mediated systemic anaphylaxis}

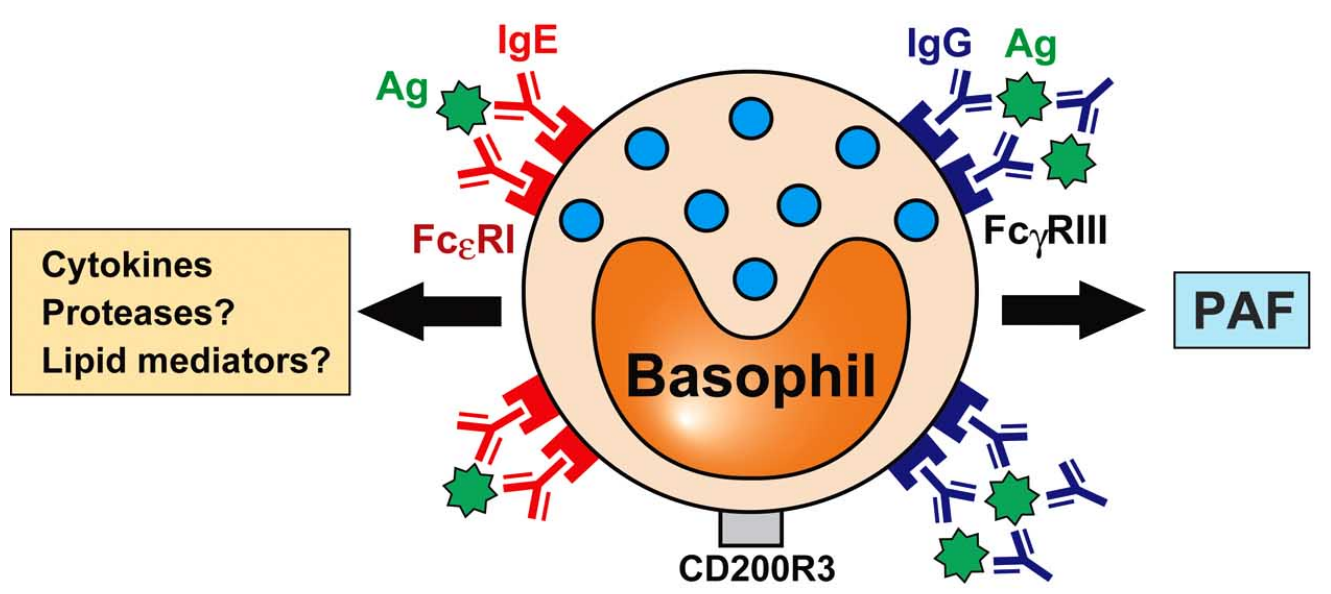

Fig. (1). Crucial roles of basophils in IgE-mediated chronic allergic inflammation and IgG-mediated systemic anaphylaxis.

IgE-mediated chronic allergic inflammation (Left): basophils bearing antigen-specific IgE are recruited into the peripheral tissue. Upon encounter with the relevant antigens, they are activated to secrete soluble factors, including cytokines, proteases, and lipid mediators. These factors act on surrounding tissue-resident cells to induce the chemokine production, which in turn recruits large numbers of proinflammatory cells such as eosinophils and neutrophils, leading to chronic allergic inflammation. IgG-mediated systemic anaphylaxis (right): circulating basophils efficiently capture antigen-IgG immune complexes through FcrRIII, and are activated to release PAF, which elicits systemic anaphylaxis.

known as FceRII). CD23 $3^{-/-}$mice developed IgE-CAI, whereas FcR $\gamma^{-/-}$mice that were deficient for FceRI failed to do so, demonstrating that FceRI-expressing cells other than mast cells are responsible for IgE-CAI. Basophils were the best candidate for these cells, but tools suitable for analyzing basophil functions, including basophil-depleting antibodies and mice deficient only for basophils were not available at that time. Therefore, we performed cell-transfer experiments in which various fractions of bone-marrow cells isolated from wild-type mice were adoptively transferred into $\mathrm{FcR} \gamma^{-/-}$ mice [24]. The adoptive transfer of the CD49b (DX5) ${ }^{+}$fraction, which represented $3 \sim 4 \%$ of the nucleated bone-marrow cells, reconstituted the IgE-CAI response in the recipient mice. On the other hand, the adoptive transfer of wild-type bone-marrow cells devoid of the $\mathrm{CD} 49 \mathrm{~b}^{+}$fraction did not confer IgE-CAI on the recipient $\mathrm{FcR} \gamma^{-1-}$ mice. These results implied that the $\mathrm{CD} 49 \mathrm{~b}^{+}$fraction of wild-type bone-marrow cells contained the FceRI-expressing cells responsible for IgE-CAI. Although the majority of $\mathrm{CD}_{4} 9 \mathrm{~b}^{+}$bone-marrow cells were NK1.1 ${ }^{+}$FceRI ${ }^{-}$NK cells, as expected, $15-20 \%$ were negative for NK1.1 and c-kit, and they expressed FceRI on their surface, indicating that they were not NK cells or mast cells. Light microscopic examination demonstrated that the $\mathrm{CD} 49 \mathrm{~b}^{+} \mathrm{Fc} \mathrm{RI}^{+}$cells possessed lobulated and often ringlike nuclei. Giemsa stained almost no granules in their cytoplasm, but electron microscopic examination revealed electron-dense granules, characteristic of and consistent with their identification as basophils. From these findings, we concluded that the $\mathrm{CD} 49 \mathrm{~b}^{+} \mathrm{Fc \varepsilon RI}{ }^{+}$basophils were responsible for the development of IgE-CAI [24].

Flow cytometric analysis of cells isolated from the IgECAI skin lesions demonstrated that, although basophils were indeed recruited to the skin lesions, they accounted for only $\sim 2 \%$ of the isolated cells, in sharp contrast to the massive infiltration of basophils in guinea pig CBH. Eosinophils and neutrophils were the major infiltrates in mouse IgE-CAI. It is extremely difficult to detect basophils in tissue sections by light microscopy, and therefore their identification with electron microscopy has been recommended $[4,5]$. To simplify the identification of mouse basophils in tissue sections, we recently established a mAb specific to mouse mast cell protease 8 (mMCP-8), a granzyme B-like serine protease that is selectively expressed by mouse basophils and stored in their secretory granules [48]. The immunohistochemical examination of paraffin-embedded skin samples with this mAb demonstrated the infiltration of a relatively small number of basophils in the dermis at the site of antigen administration. An obvious question raised by this finding was how such a small number of basophils could induce an allergic inflammation associated with a massive infiltration of eosinophils and neutrophils.

Mice deficient only for basophils have not been identified or established yet. Instead, we have developed an antiCD200R3 mAb, Ba103, that can transiently deplete most of the basophils when administered to mice [25]. CD200R3 is a member of the CD200R family, and functions as an activating receptor in association with an ITAM-containing adaptor molecule, DAP12 [49-52]. Its ligand remains to be identified. The treatment of mice with Ba103 selectively depletes the basophils without affecting the number of mast cells, even though both basophils and mast cells express CD200R3. The Ba103-mediated depletion of basophils before the antigen challenge completely abolished the development of IgE-CAI, confirming the critical role for basophils in IgE-CAI [25]. Moreover, treatment with Ba103 during the course of the dermatitis suppressed the on-going ear swelling and inflammation. Intriguingly, the number of eosinophils and neutrophils infiltrating the skin lesions was drastically 
reduced by the treatment, coincident with the ablation of basophils from the inflammation sites [25]. A similar observation was reported in a guinea pig model of tick infestation, in which the depletion of basophils by an anti-basophil serum resulted in a decreased infiltration of eosinophils at the tick feeding site [53]. These results strongly suggested that basophils might function as initiators or propagators rather than as effectors of the allergic inflammation, and that they promote the recruitment of other proinflammatory cells such as eosinophils and neutrophils. The molecules involved in this process remain to be determined. Our preliminary results suggest that antigen/IgE-stimulated basophils secrete soluble factors that include cytokines and proteases that may (Fig. 1, left) act on skin-resident cells such as fibroblasts to produce a large quantity of chemokines. These chemokines may in turn recruit the eosinophils and neutrophils. Future studies are needed to clarify how basophils are recruited to the sites of antigen exposure to initiate IgE-CAI.

It is important to know whether the IgE-CAI-type allergic reaction identified in the mouse model indeed contributes to the pathogenesis of human allergic disorders. Although no definitive evidence for this idea has been acquired to date, several observations suggest that IgE and basophils contribute to human allergic responses. A correlation between the disease severity and serum IgE levels was reported in patients with asthma or atopic dermatitis, particularly in young patients $[54,55]$. The beneficial effect of a humanized antiIgE antibody (Omalizumab) in some asthma patients [56-58] further supports the idea that $\operatorname{IgE}$ contributes to the pathogenesis of human chronic allergic disorders. The involvement of basophils in human allergy is less clear, but basophils are often observed in affected tissues in patients with allergic disorders including asthma and atopic dermatitis [14-19], and may contribute to the pathogenesis of chronic urticaria $[59,60]$.

\section{THE ROLE OF BASOPHILS IN SYSTEMIC ANA- PHYLAXIS}

Anaphylaxis is an acute-onset, potentially fatal, systemic allergic reaction $[61,62]$. The phenomenon of anaphylaxis was first described at the beginning of the $20^{\text {th }}$ century. Charles Robert Richet, who received the Nobel Prize in Physiology or Medicine in 1913, and his colleague Paul Portier reported the unexpected fatal reaction in dogs that were immunized with a non-lethal dose of venom from sea anemones and then challenged with a small dose of the venom [63, 64]. They originally intended to tolerize the dogs to the venom by immunizing them with it, on the basis of the discovery of antitoxin (neutralizing antibody against bacterial toxin) by Shibasaburo Kitasato and Emil von Behring. However, the outcome was completely opposite to their intention. Therefore, they designated this curious phenomenon anaphylaxis, which was derived from the Greek words a- (against) and phylaxis (protection). Kimishige Ishizaka and Teruko Ishizaka dedicated their efforts to elucidating the mechanism for toxin-induced anaphylaxis, and in the mid-1960s they discovered a novel antibody isotype, IgE, as a key element for provoking anaphylaxis $[65,66]$.

It is well documented that mast cells are critically involved in IgE-mediated systemic anaphylaxis [67-69]. In individuals that have been sensitized to a given allergen and produce allergen-specific IgE, re-exposure to the same allergen triggers the activation of mast cells through allergeninduced cross-linking of IgE-bound FceRI on the cell surface, leading to their release of chemical mediators such as histamine. Such mediators act on various cells, including vascular endothelial cells and bronchial smooth muscle, provoking anaphylactic symptoms such as hypotension and dyspnea [67-70]. Basophils can release histamine and leukotriene $\mathrm{C} 4$ in vitro in response to various stimuli, including FceRI cross-linking [3, 8]. Therefore, basophils have been considered likely contributors to systemic anaphylaxis. Indeed, basophils are clinically utilized to examine the sensitization status of allergic patients as mast-cell surrogates. Basophils isolated from patients' peripheral blood are incubated with suspected allergens, and their activation is analyzed by the degranulation assay or by flow cytometric analysis using CD203c or CD63 as an activation marker [71]. However, it is uncertain to what extent basophils contribute to systemic anaphylaxis in vivo, because they represent only $0.5 \%$ of peripheral blood leukocytes and do not usually reside in peripheral tissues, in contrast to mast cells.

Prospective studies of induced anaphylaxis for the purpose of understanding the molecular mechanism of systemic anaphylaxis are generally impractical in human subjects, because of the potential for a rapid, life-threatening reaction. Therefore, systemic anaphylaxis has been studied largely by using animal models. Studies using mouse models demonstrated that active systemic anaphylaxis can be elicited even in mice deficient for either IgE or mast cells [72, 73], indicating that the classical pathway that utilizes mast cells and IgE cannot explain all cases of anaphylaxis, and that an alternative pathway(s) exists $[67,74]$. Of note, FceRI- but not FcR $\gamma$-deficient mice could exhibit systemic anaphylaxis [7577]. FcR $\gamma$-deficient mice fail to express not only FceRI but also stimulatory IgG receptors. These results strongly suggested that IgG substitutes for IgE in the alternative pathway of systemic anaphylaxis. Indeed, antigen-specific, IgGmediated systemic anaphylaxis can be elicited in mice that are passively sensitized with antigen-specific IgG, particularly the IgG1 subclass $[75,76]$. The low-affinity IgG receptor Fc $\gamma$ RIII is largely involved in the IgG-mediated systemic anaphylaxis [77]. Collectively, the current knowledge indicates that at least two pathways can lead to systemic anaphylaxis: the classical one that is mediated by mast cells, IgE, and FceRI, and the alternative one that is mediated by nonmast cells, IgG, and Fc $\gamma$ RIII.

Our finding of a non-redundant role for basophils in IgECAI $[24,25]$ inspired us to explore whether basophils also contribute to systemic anaphylaxis, particularly to the IgGmediated pathway. For a better understanding of the cellular and molecular mechanism of IgG-mediated systemic anaphylaxis, we established a mouse model of IgG-mediated penicillin anaphylaxis, in which mice are passively sensitized with an intravenous injection of penicillin $\mathrm{V}$ (PenV)specific IgG1 mAb [28]. An intravenous injection of PenVconjugated bovine serum albumin (PenV-BSA) induced typical anaphylactic manifestations, including a drastic drop $\left(-4 \sim-6^{\circ} \mathrm{C}\right)$ in body temperature. Consistent with previous reports using other models, the IgG1-mediated systemic anaphylaxis was induced even in mast cell-deficient mice, although the depression in temperature was slightly less than 
in mast cell-sufficient mice. By contrast, IgE-mediated systemic anaphylaxis was completely abolished in mast celldeficient mice. Thus, mast cells are essential for the IgEmediated anaphylaxis, but dispensable for the IgG-mediated one.

FcyRIII does not efficiently bind free monomeric IgG, and shows a high affinity for immune complexes composed of IgG and antigens [78], suggesting that cells responsible for the IgG-mediated systemic anaphylaxis should quickly capture, through their Fc $\gamma$ RIII, immune complexes that are formed in the circulation soon after antigens are delivered into the bloodstream. Flow cytometric analyses revealed that basophils bind the greatest amount of immune complexes per cell among the cells analyzed, including macrophages and neutrophils, when examined immediately after the antigen challenge [28]. This binding was strongly inhibited in mice treated with anti-FcyRII-III mAb prior to the IgG1 sensitization. These results suggested that basophils are good candidates for cells responsible for IgG-mediated systemic anaphylaxis. Indeed, the Ba103-mediated depletion of basophils before the antigen challenge ameliorated the IgG-mediated systemic anaphylaxis in both mast cell-sufficient and mast cell-deficient mice [28]. On the other hand, mice depleted of macrophages, NK cells, or neutrophils exhibited normal IgG-mediated anaphylaxis in our experimental system. Importantly, the basophil depletion did not ameliorate IgEmediated anaphylaxis. Collectively, these results indicate that basophils are dispensable for the IgE-mediated anaphylaxis, but play the major role in the IgG-mediated one (Fig. 1, right).

Not only systemic, but also local IgG-mediated anaphylaxis can be induced in mice. Intradermal injection of IgG1 followed by intravenous injection of the corresponding antigens induces a local skin reaction that is called passive cutaneous anaphylaxis (PCA) [79]. IgG-mediated PCA is dependent on Fc $\gamma$ RIII [80], like IgG-mediated systemic anaphylaxis, but cannot be elicited in the absence of mast cells [81], in contrast to IgG-mediated systemic anaphylaxis, indicating that mast cells play a critical role in IgG-mediated PCA. In fact, the degranulation of mast cells was observed when they were incubated ex vivo with antigen-IgG complexes [80]. In contrast, during IgG-mediated systemic anaphylaxis, their degranulation was rarely detected in peripheral tissues [76]. The differential contribution of mast cells and basophils to local and systemic anaphylaxis, respectively, may be explained by the difference in their anatomical localization and the route of antibody administration. Antibodies are directly delivered into the skin tissue in the PCA model, and thus, tissue-resident mast cells rather than circulating basophils are mainly activated by immune complexes that form within the skin tissue. On the other hand, in the model of passive systemic anaphylaxis, both antibodies and antigens are delivered into the bloodstream, and immune complexes are formed in the circulation, leading to the activation of circulating basophils rather than of tissue-resident mast cells.

In IgE-mediated systemic anaphylaxis, mast cell-derived histamine is the major chemical mediator for inducing anaphylactic symptoms. The treatment of mice with antihistamine showed little or no inhibitory effect on IgG- mediated anaphylaxis, in contrast to its prominent effect on IgE-mediated anaphylaxis. Of note, an antagonist of plateletactivating factor (PAF) almost completely inhibited the IgGmediated anaphylaxis [28], whereas it had much less effect on IgE-mediated anaphylaxis than did the anti-histamine treatment. Thus, PAF rather than histamine is the major chemical mediator in IgG-mediated anaphylaxis (Fig. 1, right), in contrast to IgE-mediated anaphylaxis. Although many types of cells, including macrophages and neutrophils, are reported to produce PAF, basophils release much higher amounts of PAF than other cells when stimulated ex vivo with allergen-IgG1 immune complexes. PAF released from activated basophils acted on human umbilical vein endothelial cells and induced morphological changes, such as contraction and the loss of reciprocal contact.

These ex vivo observations strongly suggested that circulating basophils are stimulated to release PAF through the capture of allergen-IgG immune complexes. The PAF in turn acts on endothelial cells, resulting in increased vascular permeability, and leading to systemic anaphylaxis. However, we wondered if the amount of PAF released from basophils is sufficient to induce anaphylaxis in vivo, given that basophils account for only $0.5 \%$ of peripheral blood leukocytes. The intravenous injection of histamine or PAF alone induced a drastic drop $\left(-5^{\circ} \mathrm{C}\right)$ in body temperature as observed in IgGmediated systemic anaphylaxis. Notably, the dose necessary for inducing such a temperature drop differed considerably: $3 \mathrm{mg}$ of histamine or $100 \mathrm{ng}$ of PAF. We estimated from ex vivo experiments that $100 \mathrm{ng}$ of PAF can be released from 3 x $10^{5}$ basophils, which is close to the total number of basophils in a mouse [28]. Collectively, these data indicate that basophils can induce systemic anaphylaxis through the release of the potent vasoamine PAF in response to the stimulation of allergen- $\operatorname{IgG}$ immune complexes, even though they represent a minor population in the peripheral blood.

Passive systemic anaphylaxis is a simple and convenient model of anaphylaxis, but it may not be relevant to what happens in real life. Therefore, we examined the role of basophils in active systemic anaphylaxis, in which mice are immunized with PenV-conjugated ovalbumin in Alum and $B$. pertussis toxin, and 2 weeks later challenged by an intravenous injection of PenV-BSA [28]. Severe systemic anaphylaxis was induced in both mast cell-sufficient and deficient mice, and all the mice examined died from anaphylactic shock. In contrast, IgE- or IgG-mediated passive systemic anaphylaxis is not fatal. Ba103-mediated depletion of the basophils before the antigen challenge protected mast cell-deficient mice from death, even though some drop in body temperature was detected, clearly demonstrating that basophils play a critical role in active systemic anaphylaxis as well as in IgG-mediated passive systemic anaphylaxis. Notably, the basophil depletion failed to protect mast cellsufficient mice from death, indicating that fatal anaphylaxis can be avoided only when both basophils and mast cells are absent. Therefore, both basophils and mast cells appear to contribute critically to active systemic anaphylaxis, most likely via their respective stimulation with IgG- or IgEimmune complexes.

Another study reported an important role for macrophages in a different model of active systemic anaphylaxis, 
in which mice were immunized with goat anti-mouse $\operatorname{IgD}$ antiserum to induce a large production of $\operatorname{IgE}$ and $\operatorname{IgG}$ antibodies specific to goat $\mathrm{IgG}$, and subsequently challenged with an intravenous injection of goat $\operatorname{IgG}$ [77]. Systemic anaphylaxis was induced even in mast cell-deficient or FceRI-deficient mice, and it was completely inhibited by the PAF antagonist. The anaphylaxis was prevented, however, in wild-type mice by treating them with a macrophage inactivator, gadolinium chloride, before the antigen challenge, demonstrating that macrophages play a major role in this model system. It is unclear what determines whether basophils or macrophages play the dominant role in active systemic anaphylaxis. Candidates for this role include the genetic background of the mice, the immunization protocol, the Th1/Th2 balance, the nature of the antigen, and the quantities of antigens and antibodies.

For the clinical response to anaphylactic shock, the prompt intramuscular injection of epinephrine is the first choice for treatment, regardless of the underlying mechanism. On the other hand, the ability to distinguish the molecular mechanisms underlying different types of systemic anaphylaxis is essential for risk management and preventing recurrence [62]. It remains to be clarified whether the alternative anaphylaxis pathway mediated by basophils, $\mathrm{IgG}$, and PAF is operative in humans. There is some circumstantial evidence for it, particularly in clinical settings. Several case reports described anaphylaxis that occurred in the absence of detectable allergen-specific IgE in serum or without increased serum levels of tryptase, which is derived from degranulated mast cells $[82,83]$. In addition, allergen-specific IgG instead of IgE was reported in individuals who showed systemic anaphylaxis in response to medicines such as protamine, dextran, and recombinant $\mathrm{IgG}$ used for antibody therapy [82, 84-86]. Furthermore, human basophils have been shown to release PAF in response to various stimuli [87]. Moreover, a recent clinical study showed a correlation between serum PAF levels and the severity of anaphylaxis [88]. Therefore, the pretreatment of patients at high risk for anaphylaxis with both a PAF antagonist and an antihistamine before administering medications may avert the induction of systemic anaphylaxis.

\section{CONCLUDING REMARKS}

The functional significance of basophils has often been questioned, since evidence that basophils and mast cells play distinct roles in vivo was lacking until recently. However, as discussed in this review article, recent studies have illuminated at least some of the nonredundant roles played by basophils in allergic responses. We now know that, at least in mouse, basophils are a major player in IgG-mediated systemic anaphylaxis and that they function as initiators rather than effectors in IgE-mediated chronic allergic inflammation, even though they account for less than $1 \%$ of peripheral blood leukocytes. It remains to be clarified whether these findings are relevant to the pathogenesis of human allergic disorders. Nevertheless, the therapeutic and preventive effects of treatment with the basophil-depleting antibody on IgE-mediated chronic allergic inflammation and IgGmediated systemic anaphylaxis, respectively, in mouse mod- els, suggests that basophils and their products are promising therapeutic targets for allergic disorders.

\section{ACKNOWLEDGMENTS}

Our works described in this review article was supported by research grants (to HK) from JST, CREST, the Japanese Ministry of Education, Culture, Sports, Science and Technology, Takeda Science Foundation, the Mitsubishi Foundation, the Naito Foundation, and the Uehara Memorial Foundation.

\section{REFERENCES}

[1] Galli SJ. Mast cells and basophils. Curr Opin Hematol 2000; 7 : 32-9.

[2] Prussin C, Metcalfe DD. 4. IgE, mast cells, basophils, and eosinophils. J Allergy Clin Immunol 2003; 111: S486-94.

[3] Falcone FH, Haas H, Gibbs BF. The human basophil: a new appreciation of its role in immune responses. Blood 2000; 96: 4028-38.

[4] Dvorak AM, Nabel G, Pyne K, Cantor H, Dvorak HF, Galli SJ. Ultrastructural identification of the mouse basophil. Blood 1982; 59: $1279-85$.

[5] Dvorak AM. The mouse basophil, a rare and rarely recognized granulocyte. Blood 2000; 96: 1616-7.

[6] Urbina C, Ortiz C, Hurtado I. A new look at basophils in mice. Int Arch Allergy Appl Immunol 1981; 66: 158-60.

[7] Seder RA, Paul WE, Dvorak AM, et al. Mouse splenic and bone marrow cell populations that express high-affinity Fc epsilon receptors and produce interleukin 4 are highly enriched in basophils. Proc Natl Acad Sci U S A 1991; 88: 2835-9.

[8] Schroeder JT, MacGlashan DW, Jr., Lichtenstein LM. Human basophils: mediator release and cytokine production. Adv Immunol 2001; 77: 93-122.

[9] Min B, Prout M, Hu-Li J, et al. Basophils produce IL-4 and accumulate in tissues after infection with a Th2-inducing parasite. $\mathrm{J}$ Exp Med 2004; 200: 507-17.

[10] Voehringer D, Shinkai K, Locksley RM. Type 2 immunity reflects orchestrated recruitment of cells committed to IL-4 production. Immunity 2004; 20: 267-77.

[11] Falcone FH, Zillikens D, Gibbs BF. The 21st century renaissance of the basophil? Current insights into its role in allergic responses and innate immunity. Exp Dermatol 2006; 15: 855-64.

[12] Min B, Paul WE. Basophils and type 2 immunity. Curr Opin Hematol 2008; 15: 59-63.

[13] Voehringer D. The role of basophils in helminth infection. Trends Parasitol 2009; 25: 551-6.

[14] Macfarlane AJ, Kon OM, Smith SJ, et al. Basophils, eosinophils, and mast cells in atopic and nonatopic asthma and in late-phase allergic reactions in the lung and skin. J Allergy Clin Immunol 2000; 105: 99-107.

[15] Plager DA, Weiss EA, Kephart GM, et al. Identification of basophils by a mAb directed against pro-major basic protein 1 . J Allergy Clin Immunol 2006; 117: 626-34.

[16] Irani AM, Huang C, Xia HZ, et al. Immunohistochemical detection of human basophils in late-phase skin reactions. J Allergy Clin Immunol 1998; 101: 354-62.

[17] Gauvreau GM, Lee JM, Watson RM, Irani AM, Schwartz LB, O'Byrne PM. Increased numbers of both airway basophils and mast cells in sputum after allergen inhalation challenge of atopic asthmatics. Am J Respir Crit Care Med 2000; 161: 1473-8.

[18] Koshino T, Arai Y, Miyamoto Y, et al. Airway basophil and mast cell density in patients with bronchial asthma: relationship to bronchial hyperresponsiveness. J Asthma 1996; 33: 89-95.

[19] Nouri-Aria KT, Irani AM, Jacobson MR, et al. Basophil recruitment and IL-4 production during human allergen-induced late asthma. J Allergy Clin Immunol 2001; 108: 205-11.

[20] Karasuyama H, Mukai K, Tsujimura Y, Obata K. Newly discovered roles for basophils: a neglected minority gains new respect. Nat Rev Immunol 2009; 9: 9-13.

[21] Min B. Basophils: what they 'can do' versus what they 'actually do'. Nat Immunol 2008; 9: 1333-9.

[22] Sullivan BM, Locksley RM. Basophils: a nonredundant contributor to host immunity. Immunity 2009; 30: 12-20. 
[23] Sokol CL, Medzhitov R. Emerging functions of basophils in protective and allergic immune responses. Mucosal Immunol 2010; 3: 129-37.

[24] Mukai K, Matsuoka K, Taya C, et al. Basophils play a critical role in the development of IgE-mediated chronic allergic inflammation independently of T cells and mast cells. Immunity 2005; 23: 191202.

[25] Obata K, Mukai K, Tsujimura Y, et al. Basophils are essential initiators of a novel type of chronic allergic inflammation. Blood 2007; 110: 913-20.

[26] Sokol CL, Barton GM, Farr AG, Medzhitov R. A mechanism for the initiation of allergen-induced $\mathrm{T}$ helper type 2 responses. Nat Immunol 2008; 9: 310-8.

[27] Denzel A, Maus UA, Rodriguez GM, et al. Basophils enhance immunological memory responses. Nat Immunol 2008; 9: 733-42.

[28] Tsujimura Y, Obata K, Mukai K, et al. Basophils play a pivotal role in immunoglobulin-G-mediated but not immunoglobulin-Emediated systemic anaphylaxis. Immunity 2008; 28: 581-9.

[29] Ohnmacht C, Voehringer D. Basophil effector function and homeostasis during helminth infection. Blood 2009; 113: 2816-25.

[30] Sokol CL, Chu NQ, Yu S, Nish SA, Laufer TM, Medzhitov R. Basophils function as antigen-presenting cells for an allergeninduced T helper type 2 response. Nat Immunol 2009; 10: 713-20.

[31] Perrigoue JG, Saenz SA, Siracusa MC, et al. MHC class IIdependent basophil-CD4+ $\mathrm{T}$ cell interactions promote $\mathrm{T}(\mathrm{H}) 2$ cytokine-dependent immunity. Nat Immunol 2009; 10: 697-705.

[32] Yoshimoto T, Yasuda K, Tanaka H, et al. Basophils contribute to $\mathrm{T}(\mathrm{H}) 2-\mathrm{IgE}$ responses in vivo via IL-4 production and presentation of peptide-MHC class II complexes to CD4+ T cells. Nat Immunol 2009; 10: 706-12.

[33] Kim S, Shen T, Min B. Basophils can directly present or crosspresent antigen to CD8 lymphocytes and alter CD8 T cell differentiation into IL-10-producing phenotypes. J Immunol 2009; 183: 3033-9.

[34] Katz SI. Recruitment of basophils in delayed hypersensitivity reactions. J Invest Dermatol 1978; 71: 70-5.

[35] Jones TD, Mote JR. The phases of foreign protein sensitized in human beings. N Engl J Med 1934; 210: 120-3.

[36] Richerson HB, Dvorak HF, Leskowitz S. Cutaneous basophil hypersensitivity. I. A new look at the Jones-Mote reaction, general characteristics. J Exp Med 1970; 132: 546-57.

[37] Dvorak HF, Dvorak AM, Simpson BA, Richerson HB, Leskowitz S, Karnovsky MJ. Cutaneous basophil hypersensitivity. II. A light and electron microscopic description. J Exp Med 1970; 132: 558-82.

[38] Dvorak HF, Simpson BA, Bast RC, Jr., Leskowitz S. Cutaneous basophil hypersensitivity. 3. Participation of the basophil in hypersensitivity to antigen-antibody complexes, delayed hypersensitivity and contact allergy. Passive transfer. J Immunol 1971; 107: 138-48.

[39] Graziano FM, Gunderson L, Larson L, Askenase PW. IgE antibody-mediated cutaneous basophil hypersensitivity reactions in guinea pigs. J Immunol 1983; 131: 2675-81.

[40] Haynes JD, Rosenstein RW, Askenase PW. A newly described activity of guinea pig IgG1 antibodies: transfer of cutaneous basophil reactions. J Immunol 1978; 120: 886-94.

[41] Galli SJ, Colvin RB, Verderber E, et al. Preparation of a rabbit anti-guinea pig basophil serum: in vitro and in vivo characterization. J Immunol 1978; 121: 1157-66.

[42] Turner H, Kinet JP. Signalling through the high-affinity $\operatorname{IgE}$ receptor Fc epsilonRI. Nature 1999; 402: B24-30.

[43] Oettgen HC, Geha RS. IgE in asthma and atopy: cellular and molecular connections. J Clin Invest 1999; 104: 829-35.

[44] Gould HJ, Sutton BJ, Beavil AJ, et al. The biology of IGE and the basis of allergic disease. Annu Rev Immunol 2003; 21: 579-628.

[45] Galli SJ, Nakae S, Tsai M. Mast cells in the development of adaptive immune responses. Nat Immunol 2005; 6: 135-42.

[46] Matsuoka K, Taya C, Kubo S, et al. Establishment of antigenspecific IgE transgenic mice to study pathological and immunobiological roles of IgE in vivo. Int Immunol 1999; 11: 98794.

[47] Sato E, Hirahara K, Wada Y, et al. Chronic inflammation of the skin can be induced in IgE transgenic mice by means of a single challenge of multivalent antigen. J Allergy Clin Immunol 2003; 111: $143-8$.
[48] Ugajin T, Kojima T, Mukai K, et al. Basophils preferentially express mouse Mast Cell Protease 11 among the mast cell tryptase family in contrast to mast cells. J Leukoc Biol 2009; 86: 1417-25.

[49] Gorczynski R, Chen Z, Kai Y, Lee L, Wong S, Marsden PA. CD200 is a ligand for all members of the CD200R family of immunoregulatory molecules. J Immunol 2004; 172: 7744-9.

[50] Wright GJ, Cherwinski H, Foster-Cuevas M, et al. Characterization of the CD200 receptor family in mice and humans and their interactions with CD200. J Immunol 2003; 171: 3034-46.

[51] Voehringer D, Rosen DB, Lanier LL, Locksley RM. CD200 receptor family members represent novel DAP12-associated activating receptors on basophils and mast cells. J Biol Chem 2004; 279: 54117-23.

[52] Kojima T, Obata K, Mukai K, et al. Mast cells and basophils are selectively activated in vitro and in vivo through CD200R3 in an IgE-independent manner. J Immunol 2007; 179: 7093-100.

[53] Brown SJ, Galli SJ, Gleich GJ, Askenase PW. Ablation of immunity to Amblyomma americanum by anti-basophil serum: cooperation between basophils and eosinophils in expression of immunity to ectoparasites (ticks) in guinea pigs. J Immunol 1982; 129: 790-6.

[54] Burrows B, Martinez FD, Halonen M, Barbee RA, Cline MG. Association of asthma with serum $\mathrm{IgE}$ levels and skin-test reactivity to allergens. N Engl J Med 1989; 320: 271-7.

[55] Schafer T, Heinrich J, Wjst M, Adam H, Ring J, Wichmann HE. Association between severity of atopic eczema and degree of sensitization to aeroallergens in schoolchildren. J Allergy Clin Immunol 1999; 104: 1280-4

[56] Busse W, Corren J, Lanier BQ, et al. Omalizumab, anti-IgE recombinant humanized monoclonal antibody, for the treatment of severe allergic asthma. J Allergy Clin Immunol 2001; 108: 184-90.

[57] Holgate ST, Chuchalin AG, Hebert J, et al. Efficacy and safety of a recombinant anti-immunoglobulin $\mathrm{E}$ antibody (omalizumab) in severe allergic asthma. Clin Exp Allergy 2004; 34: 632-8.

[58] Holgate S, Casale T, Wenzel S, Bousquet J, Deniz Y, Reisner C. The anti-inflammatory effects of omalizumab confirm the central role of IgE in allergic inflammation. J Allergy Clin Immunol 2005; 115: 459-65.

[59] Vonakis BM, Saini SS. New concepts in chronic urticaria. Curr Opin Immunol 2008; 20: 709-16.

[60] Kaplan AP, Greaves M. Pathogenesis of chronic urticaria. Clin Exp Allergy 2009; 39: 777-87.

[61] Sampson HA, Munoz-Furlong A, Campbell RL, et al. Second symposium on the definition and management of anaphylaxis: summary report--Second national institute of allergy and infectious disease/food allergy and anaphylaxis network symposium. J Allergy Clin Immunol 2006; 117: 391-7.

[62] Simons FE, Frew AJ, Ansotegui IJ, et al. Risk assessment in anaphylaxis: current and future approaches. J Allergy Clin Immunol 2007; 120: S2-24.

[63] Cohen SG, Zelaya-Quesada M. Portier, Richet, and the discovery of anaphylaxis: a centennial. J Allergy Clin Immunol 2002; 110: 331-6.

[64] Richet G. The discovery of anaphylaxis, a brief but triumphant encounter of two physiologists (1902). Hist Sci Med 2003; 37: 463-9.

[65] Ishizaka K, Ishizaka T, Hornbrook MM. Physicochemical properties of reaginic antibody. V. Correlation of reaginic activity wth gamma-E-globulin antibody. J Immunol 1966; 97: 840-53.

[66] Bennich HH, Ishizaka K, Johansson SG, Rowe DS, Stanworth DR, Terry WD. Immunoglobulin E. A new class of human immunoglobulin. Immunochemistry 1968; 5: 327-8.

[67] Galli SJ. Pathogenesis and management of anaphylaxis: current status and future challenges. J Allergy Clin Immunol 2005; 115: 571-4.

[68] Bochner BS, Lichtenstein LM. Anaphylaxis. N Engl J Med 1991; 324: 1785-90.

[69] Kemp SF, Lockey RF. Anaphylaxis: a review of causes and mechanisms. J Allergy Clin Immunol 2002; 110: 341-8.

[70] Winbery SL, Lieberman PL. Histamine and antihistamines in anaphylaxis. Clin Allergy Immunol 2002; 17: 287-317.

[71] Kleine-Tebbe J, Erdmann S, Knol EF, MacGlashan DW, Jr., Poulsen LK, Gibbs BF. Diagnostic tests based on human basophils: potentials, pitfalls and perspectives. Int Arch Allergy Immunol 2006; 141: 79-90. 
[72] Jacoby W, Cammarata PV, Findlay S, Pincus SH. Anaphylaxis in mast cell-deficient mice. J Invest Dermatol 1984; 83: 302-4.

[73] Oettgen HC, Martin TR, Wynshaw-Boris A, Deng C, Drazen JM, Leder P. Active anaphylaxis in IgE-deficient mice. Nature 1994; 370: 367-70.

[74] Finkelman FD. Anaphylaxis: Lessons from mouse models. J Allergy Clin Immunol 2007; 120: 506-15.

[75] Dombrowicz D, Flamand V, Miyajima I, Ravetch JV, Galli SJ, Kinet JP. Absence of $\mathrm{Fc}$ epsilonRI alpha chain results in upregulation of $\mathrm{Fc}$ gammaRIII-dependent mast cell degranulation and anaphylaxis. Evidence of competition between Fc epsilonRI and Fc gammaRIII for limiting amounts of FcR beta and gamma chains. J Clin Invest 1997; 99: 915-25.

[76] Miyajima I, Dombrowicz D, Martin TR, Ravetch JV, Kinet JP, Galli SJ. Systemic anaphylaxis in the mouse can be mediated largely through IgG1 and Fc gammaRIII. Assessment of the cardiopulmonary changes, mast cell degranulation, and death associated with active or IgE- or IgG1-dependent passive anaphylaxis. J Clin Invest 1997; 99: 901-14

[77] Strait RT, Morris SC, Yang M, Qu XW, Finkelman FD. Pathways of anaphylaxis in the mouse. J Allergy Clin Immunol 2002; 109: 658-68.

[78] Ravetch JV, Bolland S. IgG Fc receptors. Annu Rev Immunol 2001; 19: 275-90.

[79] Hirayama N, Hirano T, Kohler G, Kurata A, Okumura K, Ovary Z. Biological activities of antitrinitrophenyl and antidinitrophenyl mouse monoclonal antibodies. Proc Natl Acad Sci USA 1982; 79: 613-5.

[80] Hazenbos WL, Gessner JE, Hofhuis FM, et al. Impaired IgGdependent anaphylaxis and Arthus reaction in Fc gamma RIII (CD16) deficient mice. Immunity 1996; 5: 181-8.
[81] Arimura A, Nagata M, Takeuchi M, Watanabe A, Nakamura K, Harada M. Active and passive cutaneous anaphylaxis in WBB6F1 mouse, a mast cell-deficient strain. Immunol Invest 1990; 19: 227-33.

[82] Cheifetz A, Smedley M, Martin S, et al. The incidence and management of infusion reactions to infliximab: a large center experience. Am J Gastroenterol 2003; 98: 1315-24.

[83] Dybendal T, Guttormsen AB, Elsayed S, Askeland B, Harboe T, Florvaag E. Screening for mast cell tryptase and serum IgE antibodies in 18 patients with anaphylactic shock during general anaesthesia. Acta Anaesthesiol Scand 2003; 47: 1211-8.

[84] Adourian U, Shampaine EL, Hirshman CA, Fuchs E, Adkinson NF, Jr. High-titer protamine-specific IgG antibody associated with anaphylaxis: report of a case and quantitative analysis of antibody in vasectomized men. Anesthesiology 1993; 78: 368-72.

[85] Kraft D, Hedin H, Richter W, Scheiner O, Rumpold H, Devey ME Immunoglobulin class and subclass distribution of dextran-reactive antibodies in human reactors and non reactors to clinical dextran. Allergy 1982; 37: 481-9.

[86] Weiss ME, Nyhan D, Peng ZK, et al. Association of protamine IgE and $\mathrm{IgG}$ antibodies with life-threatening reactions to intravenous protamine. N Engl J Med 1989; 320: 886-92.

[87] Lie WJ, Homburg CH, Kuijpers TW, et al. Regulation and kinetics of platelet-activating factor and leukotriene $\mathrm{C} 4$ synthesis by activated human basophils. Clin Exp Allergy 2003; 33: 1125-34.

[88] Vadas P, Gold M, Perelman B, et al. Platelet-activating factor, PAF acetylhydrolase, and severe anaphylaxis. N Engl J Med 2008; 358 $28-35$.

(c) Karasuyama et al.; Licensee Bentham Open.

This is an open access article licensed under the terms of the Creative Commons Attribution Non-Commercial License (http://creativecommons.org/licenses/by-nc/3.0/) which permits unrestricted, non-commercial use, distribution and reproduction in any medium, provided the work is properly cited. 